\title{
Editorial
}

11 de agosto de 2008

A revista eletrônica Contradicitio tem por finalidade divulgar trabalhos, em nível acadêmico, cujo centro de gravidade se situa em torno do papel e da presença da dialética como estilo, ou, pelo menos, como questão. Seu escopo é tão aberto quanto for possível traçar as aparições da dialética como tema, e tão preciso quanto os problemas ou as soluções que a dialética põe para si mesma como estilo filosófico. Esse primeiro número da revista reuniu artigos apresentados em Curitiba pelo Colóquio "Sobre a Fenomenologia do Espírito", os próximos acolherão artigos de procedência variada, respeitada a convergência a respeito do tema da revista - e os limites do tema "tradição dialética" determinam-se apenas pela própria atividade investigativa que a propõe ou que a abandona.

No mais, a Contradictio terá publicação semestral, seus artigos serão submetidos, o máximo possível, a pareceristas pertencentes ou próximos aos grupos de estudo ou instituições cujos interesses são próximos dos estudos hegelianos, do idealismo alemão, ou das áreas, épocas e competências em que se encaixa o artigo enviado. Não concebemos um corte abrupto de período, de nacionalidade, nem mesmo de escola, para caracterizar o que aqui chamamos de dialética, sem detrimento do evidente exemplo hegeliano fornecer, por certo, um modelo para julgar as semelhanças de família ou a dessemelhança significativa no tratamento do tema. Hegel mesmo vê a dialética surgir em Zenon e, consciente ou inconscientemente, espraiar-se até o final da modernidade. Nós, agora, podemos seguir seus passos até a mais recente contemporaneidade, até mesmo onde ela é conscientemente renegada, mas, por isso mesmo, elevada ao estatuto de tema digno de consideração.

\section{Diretrizes para o envio de artigos}

1)Os artigos deverão ser encaminhados por e-mail para o endereço contradictio@ufpr.br, em cópia eletrônica, nos formatos doc (Word), rtf (Rich Text Format), odt (BrOffice, OpenOffice, e demais editores de fonte aberta) ou pdf (com permissões para edição) . O formato recomendado envolve o uso de fontes de tamanho 11 ou 12 , o texto não deverá ultrapassar significativamente o tamanho máximo de 25 laudas.

2)O recebimento do artigo será acusado pela edição.

3)Cada artigo será enviado para pelo menos dois pareceristas, com titulação mínima de doutoramento em área afim, segundo a conveniência do tema. 
Havendo discrepância entre os pareceres o texto será enviado a um terceiro parecerista, para decisão derradeira.

4)O resultado do parecer poderá a) obstar a publicação, b) envolver sugestões para correções ou requerer resposta a objeções pontuais, ou, enfim, c) indicar a simples aprovação no estado em que se encontra o artigo. Especificamente no segundo caso (b), o artigo será encaminhado ao autor acompanhado dos pareceres que sugeriram as observações. No primeiro e no último caso, será enviada a respectiva notícia de aceitação ou recusa.

5)O artigo ficará à disposição no sítio da revista pelo tempo de, depois será arquivado com uma ligação (link) em sítio eletrônico sob responsabilidade da revista.

6)Não há exigência expressa para o caráter inédito dos artigos, mas a edição da revista reserva direito de preferência para textos inéditos.

7)O autor mantém para si todos os direitos para posteriores revisões e edições, sem prejuízo da disponibilidade do texto publicado na revista eletrônica em seu sítio, no formato e estado aprovados pelo parecer.

8) O endereço eletrônico para envio de textos, sugestões ou esclarecimentode dúvidas é contradictio@ufpr.br 